\title{
Relationship of Self-Efficacy on Diabetes Mellitus Type 2 to Self-Management Behavior in Sumbang 1st Health Center, Banyumas Regency
}

\author{
Maria Paulina Irma Susanti \\ Health Faculty \\ University Of Harapan Bangsa \\ mariapaulina@uhb.ac.id
}

\author{
Adiratna Sekar Siwi \\ Health Faculty \\ University Of Harapan Bangsa \\ adiratnasekarsiwi@uhb.ac.id
}

\begin{abstract}
Self-control is important for people with Diabetes Mellitus, this is obtained if you get support from your family. Reminding each other or controlling management is diabetics. Whether we realize it or not, when someone experiences diabetes mellitus they will experience difficult times. They must begin to improve themselves, begin to control their eating patterns and activities. It definitely needs help from people around, especially families, by telling the condition of diabetes mellitus in the closest person, it will help in diet control and treatment programs. The purpose of this research is to find out the relationship between family support and behavior of management of people with type 2 Diabetes Mellitus in public health 1 Sumbang, Banyumas Regency. Method. This type of research is correlational research with a cross sectional approach. Sampling uses a saturated sampling technique, the sample in this study were all people with Diabete Mellitus in Public health 1 Sumbang Banyumas Regency, Indonesia. 81 respondents. The data collection instrument used is a questionnaire. The results relationship of Self-Efficacy with SelfManagement of Type II Diabetes Mellitus in 1st Sumbang Banyumas Regency that the majority of respondents $(\mathbf{7 5 . 3 \%})$ or as many as 60 respondents have moderate self-efficacy and 53 respondents $(65,4 \%)$ have moderate self-management, while respondents who have less self-efficacy are 1 respondent $(1.2 \%)$ with moderate self-management that is 1 respondent $(1.2 \%)$. The results of statistical tests using Spearmans Rank showed that there was a relationship between self efficacy and self management behavior with a $p$ value of 0.001 Conclusion There is a relationship between self efficacy and self-management in people with Type II Diabetes Mellitus in Contribute 1st Public Health Center, Banyumas Regency
\end{abstract}

Keywords: self-efficacy, self-management, diabetes mellitus

\section{INTRODUCTION}

Diabetes mellitus (DM) or diabetes, including degenerative diseases. Changes in human lifestyles in the community are one of the reasons DM disease affects more and more people. Various facilities for life and various types of foods that contain high sugar and fat content, have become a scapegoat for the increasing number of people with DM in Indonesia and other countries in the world. [1]

Self-efficacy is an individual's belief in his ability to organize and perform certain tasks needed to get the expected results. Self-efficacy helps someone in making choices, efforts to progress, as well as persistence and perseverance in maintaining tasks that cover their lives. Self-efficacy can affect how a person thinks, feels, motivates himself and acts, [2]

The results of the survey conducted by researchers at Public health I Sumbang obtained the amount of data for people with DM in 2018, as many as 81 respondents. Based on the results of interviews with some people with DM basically people already understand the control of blood sugar but due to lack of family support so that confidence in the disease is also reduced. this causes the level of self-control will selfmanagement decreases

The population in this study were all people with Diabete Mellitus in Public health 1 Sumbang Banyumas Regency as many as 81 people. The sampling technique is total sampling (taking all respondents) ie 81 respondents. The interventions .were done in groups (for physical exercise) to further improve motivation and social relations among nurses in the hospital. Then the intervention supervised by experts (Physical Therapist) to be more effective. The other emphasis is the intervention is more practical if it is based on technology (eHealth). Based on the limitations of this systematic review, going forward, stronger methodological studies are needed to define the most effective and sustainable interventions for each type of work-related disease. 


\section{METHOD}

This study uses a quantitative approach with cross sectional design with the aim of identifying whether there is a relationship between the dependent variable and the independent variable in one measurement using a questionnaire measuring instrument. The purpose of this study was to analyze the relationship between family support and self-management of people with DM Family is the most important part for everyone. Similarly, for people with diabetes mellitus. Whether we realize it or not, when someone has diabetes mellitus, they will have hard times. They must begin to improve themselves, begin to control their diet and activities. It is definitely in need of help from people around especially families, by telling the condition of diabetes mellitus to the closest people, it will help in diet control and treatment programs [3]. Therefore, the family can remind or control the self-management of diabetics.

\section{RESUlTS AND DISCUSSION}

\section{Description of the respondent's characteristics}

\begin{tabular}{|c|c|c|c|}
\hline No & Variable & $\mathbf{F}$ & $\%$ \\
\hline 1 & $\begin{array}{l}\text { Job } \\
\text { Housewife laborers } \\
\text { Entrepreneur } \\
\text { Retired }\end{array}$ & $\begin{array}{l}39 \\
26 \\
12 \\
4\end{array}$ & $\begin{array}{l}48,1 \\
32,1 \\
14,8 \\
4,9\end{array}$ \\
\hline 2 & $\begin{array}{l}\text { Age } \\
35-49 \\
50-69 \text { years } \\
>70 \text { years }\end{array}$ & $\begin{array}{l}10 \\
69 \\
2 \\
\end{array}$ & $\begin{array}{l}12,3 \\
85,2 \\
2,5\end{array}$ \\
\hline 3 & $\begin{array}{l}\text { Sex } \\
\text { Male } \\
\text { Female }\end{array}$ & $\begin{array}{l}24 \\
57 \\
\end{array}$ & $\begin{array}{l}29,6 \\
70,4\end{array}$ \\
\hline 4 & $\begin{array}{l}\text { Education } \\
\text { Elementary } \\
\text { Junior } \\
\text { Senior }\end{array}$ & $\begin{array}{l}58 \\
15 \\
8\end{array}$ & $\begin{array}{l}71,6 \\
18,5 \\
9,9\end{array}$ \\
\hline 5 & $\begin{array}{l}\text { Long suffered } \\
1-5 \text { year } \\
>5 \text { year }\end{array}$ & $\begin{array}{l}58 \\
23\end{array}$ & $\begin{array}{l}71,6 \\
28,4\end{array}$ \\
\hline
\end{tabular}

Based on table 1 shows that the age of respondents is mostly in the age category 50-69 years as many as 69 respondents $(85.2 \%)$, the gender of the respondents is mostly female as many as 57 respondents (70.4\%), the last education of respondents is mostly elementary as many as 58 respondents $(71.6 \%)$, the majority of respondents' jobs were house wife as many as 39 respondents $(48.1 \%)$, and the length of time suffering from diabetes mellitus was mostly in the span of 1-5 years ie as many as 58 respondents $(48.1 \%)$.
2. Frequency Distribution of Respondents Based on Self-Efficacy

\begin{tabular}{|c|c|c|}
\hline Self Efficacy & Frekuensi (f) & $\begin{array}{c}\text { Persentase } \\
(\%)\end{array}$ \\
\hline Less & 2 & 2,5 \\
\hline Is & 60 & 74,1 \\
\hline Well & 19 & 23,5 \\
\hline Total & 81 & 100 \\
\hline
\end{tabular}

Based on table 2 Self-Efficacy in people with diabetes mellitus in Public health 1 Sumbang Banyumas Regency is mostly in the moderate category as many as 60 respondents $(74.1 \%)$.

3. Frequency Distribution of Respondents Based on Self-Management

Self

Management

(f)

(\%)

Less

1

Is

53

65,4

Well

27

33,3

Total

81

100

Based on table 3 shows that Self-Management in people with diabetes mellitus in Public health 1 Sumbang Banyumas Regency is highest in the medium category as many as 53 respondents $(65.4 \%)$ and a small portion in the less category as much as 1 respondents (1.2\%).

\section{Relationship of Self-Efficacy with Self-Management}

\begin{tabular}{|c|c|c|c|c|c|c|c|c|c|}
\hline \multirow[t]{3}{*}{ Self-Efficacy } & \multicolumn{6}{|c|}{ Self-Management } & \multirow{2}{*}{\multicolumn{2}{|c|}{ Total }} & \multirow{3}{*}{$\begin{array}{c}\mathbf{P} \\
\text { value }\end{array}$} \\
\hline & \multicolumn{2}{|c|}{ Less } & \multicolumn{2}{|c|}{ Is } & \multicolumn{2}{|c|}{ Well } & & & \\
\hline & $\mathbf{F}$ & $\%$ & $\mathbf{F}$ & $\%$ & $\mathbf{F}$ & $\%$ & $\mathbf{F}$ & $\%$ & \\
\hline Less & 1 & 1,2 & $\mathbf{0}$ & $\mathbf{0}$ & 1 & 1,2 & 1 & 1,2 & \\
\hline Is & $\mathbf{0}$ & $\mathbf{0}$ & $\begin{array}{l}5 \\
3\end{array}$ & $\begin{array}{c}65 . \\
4\end{array}$ & 7 & 8.6 & 60 & 75,3 & $\begin{array}{c}\mathbf{0 , 0 0 0} \\
\mathbf{1}\end{array}$ \\
\hline Well & $\mathbf{0}$ & $\mathbf{0}$ & $\mathbf{0}$ & $\mathbf{0}$ & $\begin{array}{l}1 \\
9 \\
\end{array}$ & 23,5 & 19 & 23,5 & \\
\hline Total & 1 & 1,2 & $\begin{array}{l}5 \\
3\end{array}$ & $\begin{array}{c}65 \\
4\end{array}$ & $\begin{array}{l}2 \\
7\end{array}$ & $\overline{33,3}$ & 81 & 100 & \\
\hline
\end{tabular}

Table 4 shows that the majority of respondents $(75.3 \%)$ or 60 respondents had moderate self-efficacy and 53 respondents $(65.4 \%)$ had moderate self-management. Based on the Spearman-rank test results obtained $p$ value is 0,000 , which means $p$ value $\leq a(0,000 \leq 0.05)$ then $\mathrm{Ho}$ is rejected and $\mathrm{Ha}$ is accepted, it can be concluded that there is a relationship between selfefficacy and self-management. 


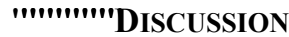

1. Characteristics of respondents based on age, sex, last education, occupation, and duration of suffering

a) Age

Age of respondents mostly in the age range 5069 years as many as 69 respondents $(85.2 \%)$.

This is in line with research conducted by [4] at

Arifin Achmad Regional Hospital of Riau

Province that of 46 respondents with diabetes mellitus, 21 of them were $45-55$ years old. In accordance with research conducted by [2] that DM sufferers in the middle age of 45-59 years were more numerous.

b) Gender

Most respondents' gender is female as many as 57 respondents $(70.4 \%)$ while male as many as 24 respondents $(29.6 \%)$. This is consistent with research conducted [5] stating that the most sex is female as many as 24 respondents $(72.7 \%)$ while men as many as 9 respondents $(27.3 \%)$. The results of this study are in line with previous studies conducted by [3] which showed that the incidence of type II DM is high in women due to a decrease in the hormone estrogen due to menopause. Research by Sari et al (2018) states that women constitute the most sex with a total of 44 respondents $(71 \%)$.

c) Last Education

Most of the respondents' last education was elementary, as many as 58 respondents $(71.6 \%)$. This is consistent with previous research conducted [5] states that the majority of respondent education is at the low education level of 21 respondents (63.6\%). Sari et al. (2018) stated that the majority of respondents had an elementary school education of 33 respondents (53.2\%). Education according to [6] influences healthy behaviors, those behaviors that are related to one's efforts or activities to maintain and improve their health. Healthy behavior includes 3 aspects, namely prevention, health improvement, and nutritional behavior. If someone is getting higher education of course the level of awareness will be higher and will affect the prevention or treatment of hypertension.

d) Work

Most respondents' occupations were housewives with 39 respondents $(48.1 \%)$.

e) Long suffer

Based on table 4.1, it was found that the length of time suffering from diabetes mellitus was mostly respondents in the range of 1-5 years, as many as 58 respondents $(48.1 \%)$. This is in line with previous research conducted [5] which states that most of the long-standing respondents suffered from diabetes mellitus in the range of 1-5 years, as many as 24 respondents $(72.7 \%)$.

2. Relationship of Self-Efficacy with SelfManagement of Type II Diabetes Mellitus in

Public health 1 Sumbang Banyumas Regency Relationship of Self-Efficacy with Self-Management of Type II Diabetes Mellitus in 1st Sumbang Banyumas Regency Based on table 4 shows that the majority of respondents $(75.3 \%)$ or as many as 60 respondents have moderate self-efficacy and 53 respondents $(65,4 \%)$ have moderate selfmanagement, while respondents who have less selfefficacy are 1 respondent $(1.2 \%)$ with moderate selfmanagement that is 1 respondent $(1.2 \%)$. The analysis notes that there is a relationship between self-efficacy and selfmanagement in people with Diabetes Mellitus Type II in Public health 1 Sumbang Banyumas Regency with a $\mathrm{p}$ value $=$

0,0001 .

This research has been attempted and carried out in accordance with scientific procedures, however it still has limitations, namely:

1. This research has limitations, namely not examined other factors that affect one's selfefficacy such as performance experience, experience of others, emotional states, or physiological states that occur in people with type II DM.

2. There is a limitation of this study using a questionnaire so that sometimes the answers given by the sample do not indicate the real situation

3. Sampling in the Public health 1 Sumbang area takes a long time and sometimes the researcher does not get a respondent.

4. Most respondents cannot read, so researchers must explain and take a considerable amount of time.

\section{CONCLUSION}

1. Most patient who suffer from diabetes mellitus in the 1st Sumbang Banyumas Regency work area have the following characteristics are Women, More than $>45$ years old, Education of elementary school, Work as a house wife and with a long period of suffering 1-5 years

2. Self-Efficacy in people with diabetes mellitus in Public health 1 Sumbang Banyumas Regency is mostly in the moderate category as many as 60 respondents

3. Self-Management among people with diabetes mellitus in Public health 1 Sumbang Banyumas Regency is highest in the medium category, which are 53 respondents

4. The majority of respondents or as many as 60 respondents had moderate self-efficacy and 53 respondents had moderate self-management.

Based on the Spearman-rank test results obtained $\mathrm{p}$ value is 0,000 , which means $p$ value $\leq a(0,000 \leq 0.05)$ 
then $\mathrm{Ho}$ is rejected and $\mathrm{Ha}$ is accepted, it can be concluded that there is a relationship between selfefficacy and self-management.

\section{Bibliography}

[1] WHO, "Media Centre World Helath Organization," 2018.

[2] N. Gita Pertiwi, "Pengaruh Self-Efficacy Terhadap Hasil Belajar pada Siswa Kelas V Sekolah Dasar Daerah Binaan Iv Kecamatan Cilacap Selatan Kabupaten Cilacap," 2015.

[3] D. Santi., "Efektivitas (Self-efficacy Enhancement Intervention Program (SEEIP)) Terhadap Efikasi Diri Manajemen Diabetes Mellitus Tipe 2.," nursingjurna, 2017.

[4] K. H. R. T. Nuraisya. F, "Dukungan Keluarga dan Kualitas Hidup Pasien Diabetes Mellitus," Journal Of Community Medicine and Public Health. , 2017.

[5] Rahmawati., " Pengaruh Program Diabetes SelfManagement Education Terhadap Manajemen Diri Pada Penderita Diabetes Mellitus Tipe 2," pdfs.semanticscholar. org, 2016.

[6] S. Notoatmodjo, Metodologi Penelitian Kesehatan, Jakarta: Rineka Cipta, 2010. 